\title{
Effect of Curing Temperature on Geopolymeric Polycondensation of Blast Furnace Slag
}

\author{
Chang Seob Jeon and Tae Woong Song ${ }^{\dagger}$
}

Department of Advanced Materials Engineering, Kyungnam University, Changwon 631-701, Korea

(Received October 4, 2011; Revised October 24, 2011; Accepted October 26, 2011)

\section{고로슬래그의 지오폴리머 축중합반응에 미치는 양생온도의 영향

\author{
전창섭 · 송태웅 ${ }^{\dagger}$
} \\ 경남대학교 신소재공학과 \\ (2011년 10월 4일 접수 ; 2011년 10월 24일 수정 ; 2011년 10월 26일 채택)}

\begin{abstract}
The effect of curing temperature on basic geopolymeric reactivity and hardening behaviour of blast furnace slag were investigated using the mixture of pulverized slag and several alkaline solutions of relatively high concentration. For the pastes prepared at several different temperatures between $20^{\circ} \mathrm{C}$ and $90^{\circ} \mathrm{C}$, setting time and heat of reaction were examined while mineralogical and morphological examinations were performed for the hardened paste after curing period at same temperature. The geopolymeric reaction of slag was revealed to be accelerated strongly according to the curing temperature regardless of the sort and concentration of the alkaline solution. The increase of concentration of the alkaline solution within $9 \mathrm{M}$ and the existence of silicic ion in the solution also promoted the reaction severely. The mineral component and their ratio of the hardened paste were revealed to be influenced by the chemical species and silicic ion contained in alkaline solution rather than by the curing temperature. The higher temperature and longer period of curing stage were effective for the sustained formation of geopolymer and succeed improvement of density and uniformity of morphology of the final hardened body.
\end{abstract}

Key words : Geopolymer, Blast furnace slag, Alkali activation, Polycondensation, Curing temperature

\section{1. 서 론}

1978년 Davidovits가 규산알미늄 또는 이의 공급원과 알 칼리용액간의 반응으로 저온에서 스스로 경화하여 생성되 는 무기질 고분자를 지오폴리머(geopolymer)라고 처음 명명 한 이래 저에너지/친환경 재료의 개발을 목적으로 이의 반 응 메커니즘, 반응할 수 있는 물질 및 경화체의 물성 등에 대한 연구가 다수 진행되었다. ${ }^{1-3)}$ 지오폴리머는 실리콘 기반 무기중합체로서 가장 단순하게는 순수한 실리카 공급원 으로부터의 $\mathrm{Si}$ 이온의 용해와 sol-gel 반응에 의해 생성되는 -Si-O-Si-O-Si- 사슬에 기초를 두고 있다. 여기에 다량의 양이 온(예 $\mathrm{Na}^{+}$)이 보충되면서 사슬이나 망목 중의 일부 $\mathrm{Si}^{4+}$ 이 온이 $\mathrm{Al}^{3+}$ 이온으로 치환된 것이 -Si-O-Si-O-Al(Na)-O-Si- 등 으로 나타낼 수 있는 지오폴리머이며, 그 다음으로는 더욱 복잡한 형태로서 알칼리 활성화 시멘트에서와 같이 지오 폴리머 sol에 $\mathrm{Ca}$ 가 도입되어 -Si-O-Si-O-Al(Ca/Na)-O-Si-로 나타낼 수 있는 비정질 상에 calcium silicate hydrate(이하

${ }^{\dagger}$ Corresponding author : Tae Woong Song

E-mail : twsong@kyungnam.ac.kr

Tel : +82-55-249-2695 Fax : +82-55-248-5033
$\mathrm{CSH}$ ) 상이 혼합된 경화체까지 지오폴리머에 포함하게 되었 다. 따라서 넓은 의미로 지오폴리머는 조성에 상관없이 알 칼리 용해와 축중합이라는 두 단계의 과정으로 형성되어 $\mathrm{Mn}\left[-\left(\mathrm{Si}-\mathrm{O}_{2}\right) \mathrm{z}-\mathrm{A} 1-\mathrm{O}\right] \mathrm{n} \cdot \mathrm{wH}_{2} \mathrm{O}(\mathrm{M}: \mathrm{Na}, \mathrm{K}, \mathrm{Ca}$ 등의 알칼리 요 소, $\mathrm{Z}: 1-3, \mathrm{n}$ : 중합도)로 표시할 수 있는 고분자 구조의 고 체 무기물을 뜻하게 되었다. ${ }^{4-6)}$ 한편 고로슬래그를 중-저 농도의 알칼리 용액으로 활성화하여 C-S-H를 생성시키는 것 은 중합반응이 아니므로 지오폴리머라 할 수 없지만 고농도 의 알칼리 용액과 반응시킬 경우엔 지오폴리머 sol에 $\mathrm{Ca}$ 가 도입된 세 번째 유형의 지오폴리머가 되며 본 연구는 여 기에 기초를 두고 있다.

제철산업의 대량의 부산물인 고로슬래그의 알칼리 활성 화 반응에 관한 연구 ${ }^{7-10)}$ 들이 다수 진행되어 왔는데 이러한 연구는 차츰 슬래그계 지오폴리머를 활용하여 기존 시멘트 가 안고 있는 $\mathrm{CO}_{2}$ 및 에너지 문제를 저감하기 위한 무시멘 트(cement-free)형 콘크리트의 제조를 궁극적인 목표로 하게 된 것으로 보인다. 기존의 포틀랜드 시멘트를 지오폴리머 시 멘트로 대체하면 $\mathrm{CO}_{2}$ 발생량이 $80 \%$ 나 감축되어 인류가 발 생하는 전체 $\mathrm{CO}_{2}$ 양의 $4-8 \%$ 를 줄일 수 있기 때문이다. ${ }^{11)}$ 이에 따라 슬래그 지오폴리머 관련 연구는 실험조건이나 
항목이 기존의 시멘트 콘크리트 관련 연구와 거의 같은 범 주에서 행해지고 있는 것이 일반적이다. 즉 몰탈이나 콘 크리트의 유동성, 응결·경화시간 및 양생과 강도발현 특 성 등이 주로 상온의 온도조건에서 연구되어지고 있다. 그 러나 슬래그 지오폴리머는 코팅 막의 제조 연구 ${ }^{12)}$ 에서와 같 이 몰탈이나 콘크리트 형태가 아닌 페이스트 상태로도 매 우 다양한 유형의 소재로 활용될 수 있고, 시멘트 2차 제품 에서의 시멘트에 대체될 수도 있으므로 성형 및 양생온 도가 꼭 일반 시멘트 콘크리트에서와 같이 상온의 범주 로 제한될 이유는 없을 것이다. 이는 약간의 온도 변화만 으로도 축·중합 반응의 거동이 매우 달라질 수 있기 때문 이다. 따라서 상온 이상의 다양한 온도에서 슬래그 분말 단 미 상태의 기본적인 지오폴리머 생성 특성을 연구할 필요 가 있다고 사료되나 이러한 보고는 잘 이루어져 있지 않다.

본 연구는 물의 비점 이하에서 고농도 알칼리 용액에 대 한 슬래그 분말의 반응성과 경화체 생성거동에 미치는 온도 의 영향을 파악함으로써 앞으로의 슬래그 지오폴리머의 다양한 응용을 위해 필요한 기초자료를 얻고자 한 것이다. 이를 위하여 몇 가지 다른 온도에서 슬래그 분말에 대표적 인 몇 가지 알칼리 수용액을 혼합하여 발열과 응결 거동, 그리고 경화체의 미세조직과 광물상을 평가하였다.

\section{2. 실험 방법}

고로슬래그(이하 슬래그)는 광양 제철소에서 발생된 것 으로서 소량의 석고를 혼합하여 시멘트 혼합재용으로 분 말도(Blaine 값) $4695 \mathrm{~cm}^{2} / \mathrm{g}$ 이 되도록 대량으로 분쇄, 공급 하는 것을 사용하였으며 이의 화학조성은 Table 1, 광물상 및 분말 형태는 Fig. 1에 나타낸 바와 같다. 지오폴리머의 물리적 성질은 네트워크의 $\mathrm{Si} / \mathrm{Al}$ 비에 영향을 받아 그 값이 3 이하일 때 견고하며 그 이상으로 높아지면 접착제용의 2차원 가교 체인에 이르기까지 점차 유연해지는 것으로

Table 1. Chemical Composition of Blast Furnace Slag used for Starting Raw Material

\begin{tabular}{cccccccc}
\hline \hline Component & $\mathrm{SiO}_{2}$ & $\mathrm{Al}_{2} \mathrm{O}_{3}$ & $\mathrm{CaO}$ & $\mathrm{Fe}_{2} \mathrm{O}_{3}$ & $\mathrm{SO}_{4}$ & $\mathrm{MgO}$ & $\mathrm{TiO}_{2}$ \\
\hline $\begin{array}{c}\text { Composition } \\
\text { (wt\%) }\end{array}$ & 26.84 & 9.92 & 53.36 & 0.86 & 5.31 & 1.47 & 0.89 \\
\hline
\end{tabular}
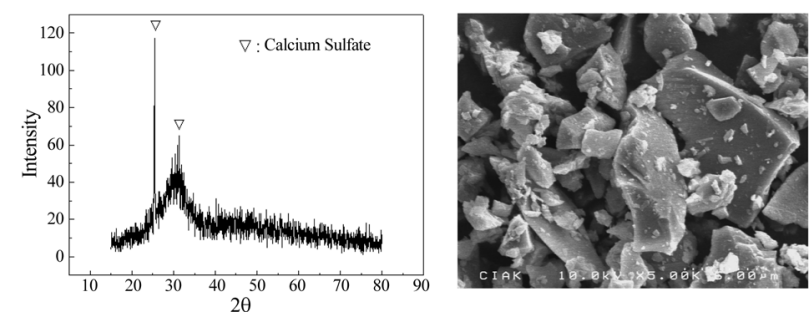

Fig. 1. XRD pattern and SEM microphotograph of blast furnace slag used for starting raw material.
알려져 있다. ${ }^{4)}$ 이러한 점에서 본 슬래그는 지오폴리머용 출발원료로서 적당한 $\mathrm{Si} / \mathrm{Al}$ 비를 가진다고 할 수 있다.

알칼리 활성화제로는 흔히 사용되는 수산화나트륨 $(\mathrm{NaOH})$ 과 수산화칼륨 $(\mathrm{KOH})$ 및 규산소다 $\left(\mathrm{Na}_{2} \mathrm{SiO}_{3}\right)$ 를 택하여 시약 1 급의 것을 사용하였다. 기초실험의 결과를 토대로 $\mathrm{NaOH}$ 와 $\mathrm{KOH}$ 의 농도가 각각 3,6 및 9몰인 여섯 종류의 수용액 과, 이들에 규산소다를 $50 \mathrm{wt} \%$ 첨가한 수용액들을 만들어 페이스트 제조용 액상성분으로 사용하였으며 $\mathrm{Na}_{2} \mathrm{SiO}_{3}$ 수 용액만으로는 페이스트 혼합 중 급결하는 경향성이 커 이 는 액상성분에서 제외하였다.

분말성분인 슬래그와 액상성분을 $20^{\circ} \mathrm{C}, 60^{\circ} \mathrm{C}$ 및 $90^{\circ} \mathrm{C}$ 상태에서 용액/분말 비 0.5 로 혼합하여 페이스트를 만든 후 밀폐용기에 주입하여 같은 온도로 설정된 양생 챔버에 각각 넣어두고 $\mathrm{KS} \mathrm{L} \mathrm{5103에} \mathrm{규정된} \mathrm{길모어} \mathrm{침(Gillmore} \mathrm{needles)}$ 장치를 응용하여 시료간의 응결시간의 차이를 비교 평가하 는 한편 $500 \mathrm{ml}$ 용량의 단열용기를 사용하여 혼합 직후부터 페이스트의 온도 변화를 측정하였다. 종결 직후 또는 일정 재령(24시간, 3 주)이 된 경화체에 대해 파단면의 미세구 조를 관찰하고 광물상을 분석하였다.

슬래그나 경화체의 화학조성과 광물상 분석에는 $\mathrm{X}$ 선 형광분석기(PW 2400, Philips, Holland)와 X선 회절분석기 (PW 3710, Philips, Holland)를 각각 사용하고 경화체의 미 세구조 관찰에는 주사전자현미경(S-4200, Hitachi, Japan)을 사용하였다.

\section{3. 결과 및 고찰}

\section{1. 페이스트의 초기 반응성}

알칼리 용액의 종류나 반응 온도의 변화가 슬래그의 초기 활성화 반응 속도에 미치는 영향을 간이 평가하기 위하여 실시한 응결시간 측정 결과를 Figs. 2 및 3에 나타내었다. Fig. 2는 우선 6 몰 용액을 사용하여 양생온도를 달리할 때 의 초결 및 종결시간의 변화를 나타낸 것으로서 이 결과는 우선 양생온도가 높아질수록 초결과 종결 시간이 모두 단 축되는 결과를 보여주고 있다. $\mathrm{NaOH}$ 나 $\mathrm{KOH}$ 를 사용한 시 료(그림의 $(\mathrm{a})$ 와 $(\mathrm{b}))$ 는 상온 $\left(20^{\circ} \mathrm{C}\right)$ 에서의 초결/종결 시간이 각각 35 분/80분 및 45 분/90분 정도이며 여기에서 $\mathrm{KOH}$ 시 료의 응결시간이 약간 긴 것은 $\mathrm{Na}^{+}$보다 $\mathrm{K}^{+}$의 크기가 큰 것 과도 관련이 있을 것으로 사료된다. 그러나 $60^{\circ} \mathrm{C}$ 이상의 온 도에서는 $\mathrm{NaOH}$ 의 경우 약 15 분, $\mathrm{KOH}$ 의 경우 약 20 분 이 내에 초결과 종결이 완료됨으로서 양생온도가 응결시간의 제어에 강력한 수단이 될 수 있음을 알 수 있다. 슬래그의 알칼리 축중합반응은 일반 시멘트의 수화반응과는 달리 단 순한 용해-석출 반응으로 볼 수 있으므로 페이스트의 응결 시간은 슬래그 성분의 용출과 지오폴리머의 생성 속도와 관련이 있을 것이다. 즉 슬래그 페이스트의 초결과 종결은 일련의 연속된 현상이지만 초결은 용액으로부터 생성된 물 

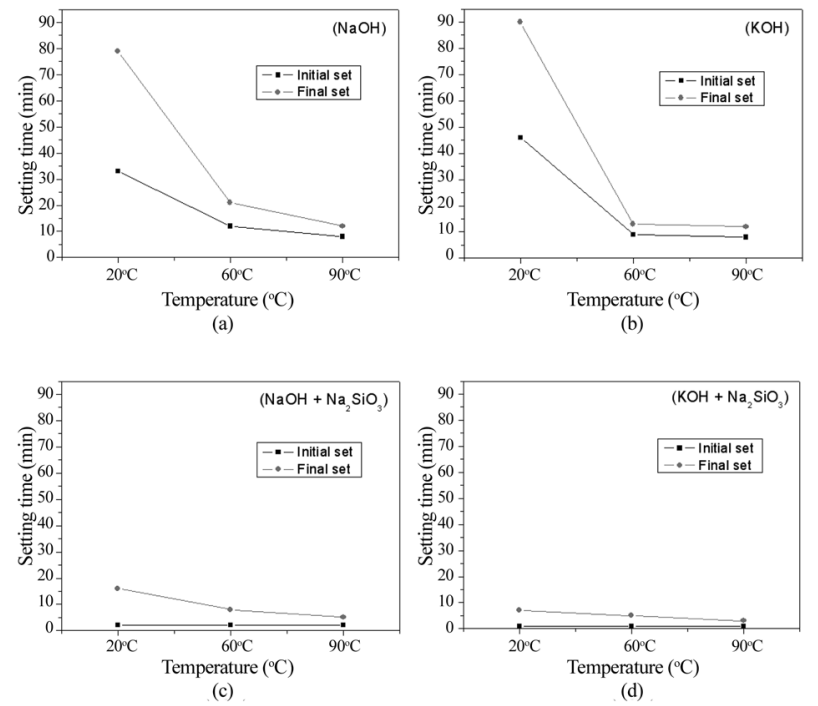

Fig. 2. The effect of curing temperature on setting time of slag paste prepared with various alkali solutions concentrated at $6 \mathrm{~mol}$.

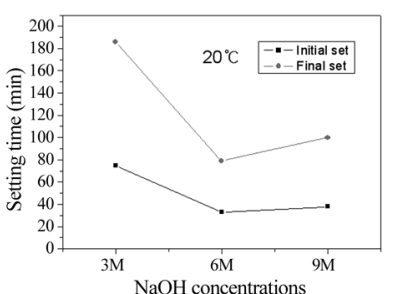

(a)

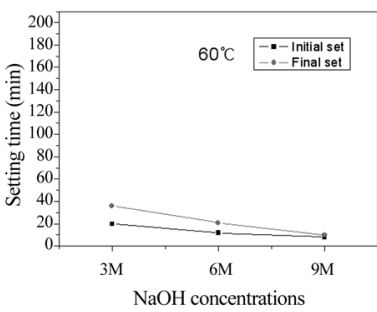

(c)

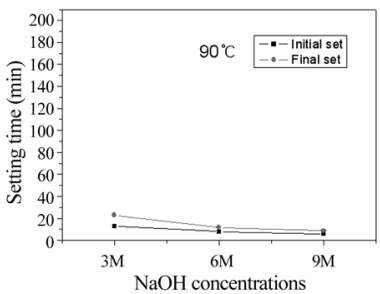

(e)

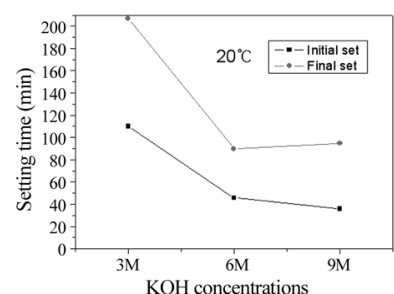

(b)

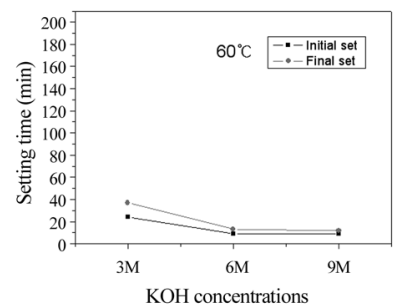

(d)

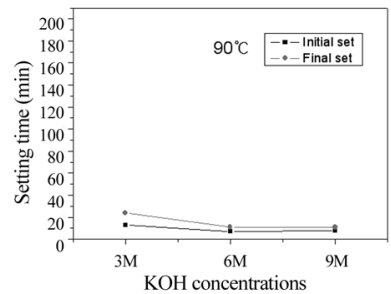

(f)
Fig. 3. The effect of concentration of alkali solutions on setting time of the slag paste at various temperature.

질에 의해 페이스트의 유동성이 사라지게 되는 시점을, 종 결은 생성된 상의 증가나 결합(interlocking, entanglement 또 는 polymerization)으로 페이스트에서 강도가 발현하기 시작 하는 시점을 침입법으로 직접 측정하는 것이므로 이로부터
시료들의 반응 속도를 간접적으로 비교, 평가할 수 있다. 슬 래그 페이스트의 응결과 경화는 강알칼리 용액 중에서 슬 래그가 용해하여 $\mathrm{SiO}_{4}$ 와 $\mathrm{AlO}_{4}$ 4면체 단위의 형성이 진행됨 에 따라 이들 사면체 단위들은 산소원자를 공유하면서 연 결되어 폴리머 전구체 $\left(\mathrm{SiO}_{4}-\mathrm{AlO}_{4}\right.$ 또는 $\mathrm{SiO}_{4}-\mathrm{AlO}_{4}-\mathrm{SiO}_{4}$ 또는 $\mathrm{SiO}_{4}-\mathrm{AlO}_{4}-\mathrm{SiO}_{4}-\mathrm{SiO}_{4}$ 등)를 만들며 이들의 양적 증가 또는 3 차원 중합에 의하여 순차적으로 초결과 종결에 이른다고 해석된다. ${ }^{9)}$ 따라서 상온부터 $90^{\circ} \mathrm{C}$ 사이의 슬래그의 알칼리 반응은 일반적인 화학반응과 같이 온도의 상승에 따라 빨라 지며 이러한 현상은 모든 용액에서 동일함을 알 수 있다. 한 편 이 그림에서는 $\mathrm{NaOH}$ 나 $\mathrm{KOH}$ 용액을 단독으로 사용한 페이스트(그림의 (a)와 (b))에 비해 규산소다를 혼합한 용액 으로 만든 페이스트(그림의 (c)와 (d))에서 응결시간이 크게 단축되는 것을 보여준다. 이는 성분상으로 볼 때 규산소다 용액의 $\mathrm{Si}$ 성분이 공통이온 효과 등의 화학적 특성으로 반응 물의 생성을 촉진한 때문인 것으로 생각되며 따라서 페이 스트에 급결을 야기하는 규산소다는 단미의 사용보다는 응 결 경화시간 촉진용의 첨가제로서 적절히 활용할 수 있을 것으로 사료된다.

Fig. 3은 기초실험 결과에 의해 적정의 작업성과 경화체 강도가 확인된 농도 범위에서 $\mathrm{NaOH}$ 용액과 $\mathrm{KOH}$ 용액의 농도 변화가 페이스트의 응결시간에 미치는 영향을 몇 가지 온도에서 측정한 결과이다. 여기에서는 우선 양생 온도에 무관하게 용액의 농도가 높을수록 응결시간이 단축되며, 온도에 의한 반응성 촉진 효과가 배제된 $20^{\circ} \mathrm{C}$ (그림의 (a)와 (b))에서는 그 경향성이 매우 뚜렷한 것을 알 수 있다. 이 로부터 슬래그의 알칼리 반응성은 실험 범위 내에서는 수 용액의 농도가 높을수록 빨라짐을 알 수 있다. 그러나 별도 의 실험에 의하면 9 몰의 농도에서는 페이스트의 유동성이 감소하므로 응결시간의 단축 수단으로는 바람직하지 않을 것으로 사료된다. 이 결과에서는 용액의 농도 외에도 앞 의 Fig. 2에서와 같이 양생온도의 상승에 따라 응결시간이 크게 단축되는 동일한 경향을 확인할 수 있다.

Fig. 4 는 $20^{\circ} \mathrm{C}$ 에서 농도 6 몰의 알칼리 용액으로 페이스트 를 제조하여 혼합 직후부터 약 12 시간까지 측정한 온도의 변화를 나타낸 것이다. 여기에서는 앞서 언급한 응결시간과 는 달리 페이스트의 온도변화 곡선은 시간의 경과에 따라 연속적으로 슬래그의 알칼리반응성에 대한 또 다른 정보를 알 수 있다. $\mathrm{NaOH}$ 나 $\mathrm{KOH}$ 용액을 사용한 페이스트(그림의 (a)와 (c))는 혼합 직후부터 단조로운 곡선으로 약 3시간 까지 온도가 급상승하여 정점을 나타내는데 비하여 규산소 다를 혼합한 용액으로 만든 페이스트(그림의 (b)와 (d))는 반응 초기에 온도곡선에 하나의 변곡점을 보이고 있다. 따 라서 발열 현상은 이 변곡점을 전후하여 두 가지의 서로 다 른 요인에 의해 나타남을 알 수 있는데 페이스트 혼합 직후 의 급상승 곡선은 규산소다의 첨가에 기인하며 변곡점 이 후에는 $\mathrm{KOH}$ 나 $\mathrm{NaOH}$ 본연의 반응에 기인한 것이라고 해 

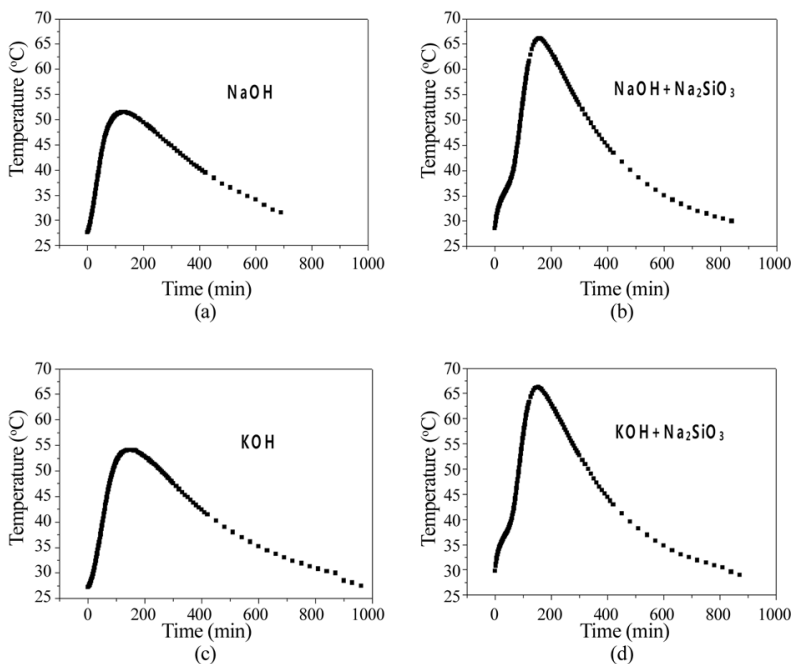

Fig. 4. Temperature change of the paste prepared from slag and $6 \mathrm{M}$ alkali solutions with and without addition of $\mathrm{Na}_{2} \mathrm{SiO}_{3}$ at $20^{\circ} \mathrm{C}$.
석된다. 이러한 2 단계 반응으로 인하여 곡선의 정점 온도 가 훨씬 높아졌으며, 이들 시료의 종결시간이 20 분 이내로 서 매우 짧았던 것은(Fig. 2의 (c)와 (d) 참조) 초기의 발열을 야기한 규산소다의 촉진제 작용 ${ }^{13)}$ 때문이라고 사료된다. 따라서 이 결과에서도 규산소다가 상온에서의 반응 촉진용 첨가제로 유용함을 보여준다. 한편 $\mathrm{NaOH}$ 에 비하여 응결시 간이 길었던 $\mathrm{KOH}$ 시료가 약간 더 높은 온도를 보인 것은 몰 농도는 같으나 알칼리도가 좀 더 큰 때문일 것이다.

\section{2. 경화체의 미세구조와 광물상}

Figs. 5, 6 및 7은 몇 가지 알칼리 용액을 사용하여 서로 다른 온도에서 24 시간 동안 양생하여 얻은 경화체의 파단면 사진을 나타낸 것이다. 이들 사진에서 볼 수 있는 바와 같 이 모든 시료의 경화 조직은 특정 형태를 띤 수화물이나 광 물상을 보이지 않고 대체적으로 치밀한 편이나 $\mathrm{NaOH}$ (Fig. 5) 보다는 $\mathrm{KOH}(\mathrm{Fig}$. 6)를 사용한 시료가 더 높은 치밀도와 균질성을 보이며 규산소다를 혼합한 시료(Fig. 7)에서 가장
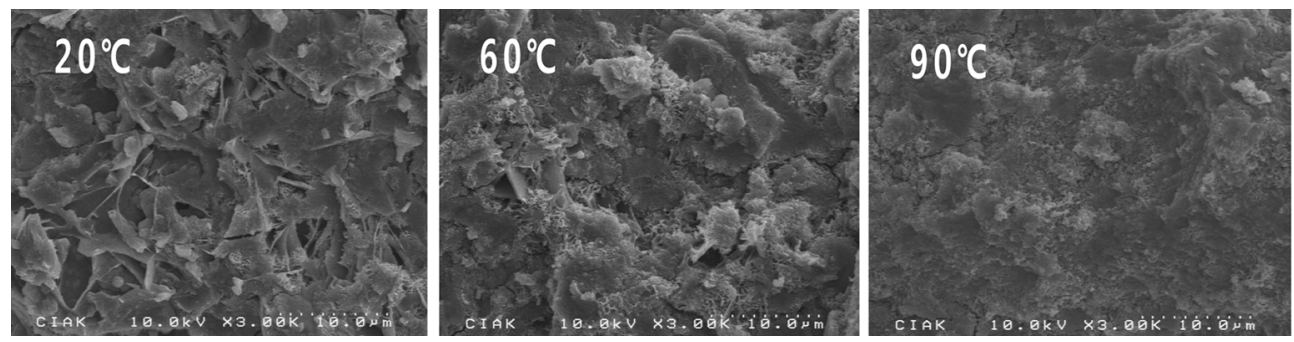

Fig. 5. SEM microphotographs of hardened slag geopolymer prepared with $6 \mathrm{M}-\mathrm{NaOH}$ solutions at different temperature for 24 h.
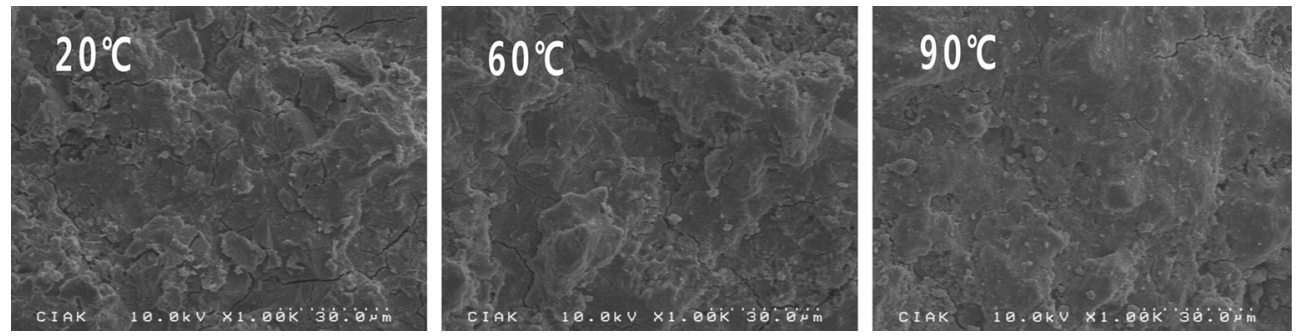

Fig. 6. SEM microphotographs of hardened slag geopolymer prepared with $6 \mathrm{M}-\mathrm{KOH}$ solutions at different temperature for $24 \mathrm{~h}$.
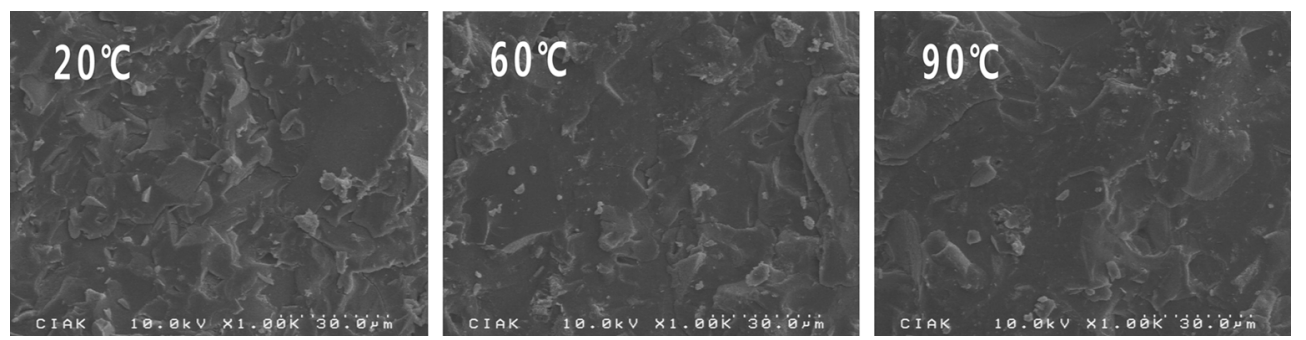

Fig. 7. SEM microphotographs of hardened slag geopolymer prepared with $\mathrm{Na}_{2} \mathrm{SiO}_{3}$-added $6 \mathrm{M}-\mathrm{NaOH}$ olutions at different temperature for $24 \mathrm{~h}$. 

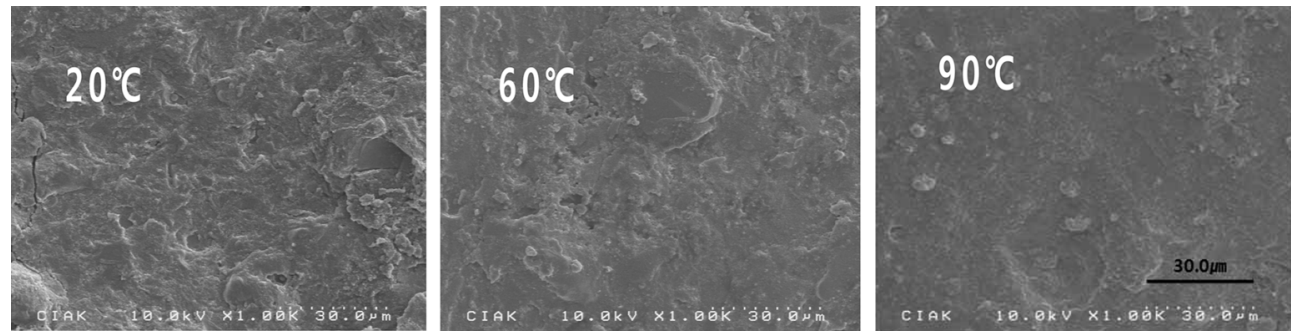

Fig. 8. SEM microphotographs of hardened slag geopoymer prepared with $6 \mathrm{M}-\mathrm{NaOH}$ solution at different temperature for 3 weeks.

치밀한 경화조직을 보이고 있다. 규산소다를 혼합한 시료의 이러한 특성은 앞의 결과에서와 같이 규산소다가 슬래그의 알칼리반응에 매우 효과적인 촉진제로 작용하였기 때문일 것이다. $\mathrm{NaOH}$ 나 $\mathrm{KOH}$ 만을 사용한 시료(Figs. 5와 6)는 양생 온도가 높아질수록 파단면이 더 균질하고 치밀해지는 것을 관찰할 수 있다. 이러한 결과는 앞에서도 고찰한 바와 같이 슬래그의 알칼리 활성화가 온도의 상승에 비례하여 촉진 됨으로서 초기 반응산물의 생성량과 축중합 반응 양이 더 증가되었기 때문이라고 생각된다.

Fig. 8은 6 몰의 $\mathrm{NaOH}$ 를 사용하여 서로 다른 온도에서 3 주 간 양생한 슬래그 지오폴리머 경화체의 파단면 사진을 나타낸 것이다. 이 사진은 전체적으로 앞의 Fig. 5에 나타낸 24시간 경화체에 비하여 훨씬 균질하고 치밀한 조직을 나 타냄으로서 재령 24시간 이후에도 상의 생성반응이 진행 되었음을 보여준다. 사슬이나 그물 형태의 지오폴리머 경화 체는 종결시간 이전에 외력(압축)을 가하지 않으면 다중 축합에 의해 시료 전체에 걸쳐 연속된 nano 또는 meso pore 의 다공체가 된다. 이 기공 내에는 최초의 혼합 용액에 포 함된 물과 축합반응 결과 생긴 물에 잉여 알칼리 금속 이온 및 미반응 silicon hydroxide가 들어있는 상태이므로 밀폐용 기 내의 시료는 평형에 이를 때까지 반응이 지속되는 것으 로 보이며 치밀한 경화체를 얻기 위해서는 충분한 시간의 양생이 필요함을 알 수 있다. 한편 이러한 고찰과 상관없이 재령 3주의 시료들도 앞의 Fig. 5(재령 24시간)에서와 같이 양생온도가 높을수록 치밀하고 균질한 조직을 보임으로서 양생온도의 상승이 슬래그 지오폴리머 생성반응을 촉진 하는 똑같은 결과를 나타내었다.

Fig. 9는 몇 가지의 다른 용액을 사용하여 만든 페이스트 를 중간 온도인 $60^{\circ} \mathrm{C}$ 에서 24 시간동안 양생하여 얻은 경화 체의 $\mathrm{X}$ 선 회절분석 결과를 나타낸 것으로서 용액 농도를 9몰로 택하여 알칼리 농도가 충분한 조건 하에서의 반응 산물을 확인하고자 한 것이다. 앞에서 본 파단면 관찰 결 과로는 외관상으로 경화체가 대부분 한 종류의 비정질 상으 로 이루어진 것 같이 보이는 데 비하여 XRD pattern은 경화 체가 대부분은 비정질 상으로 이루어졌지만 여기에 몇 가 지의 결정상이 혼재되어 있음을 보여준다. 우선 $\mathrm{NaOH}$ 나 $\mathrm{KOH}$ 를 사용한 시료(그림의 $\mathrm{a}$ 와 $\mathrm{b}$ )에서 공통적으로 지오
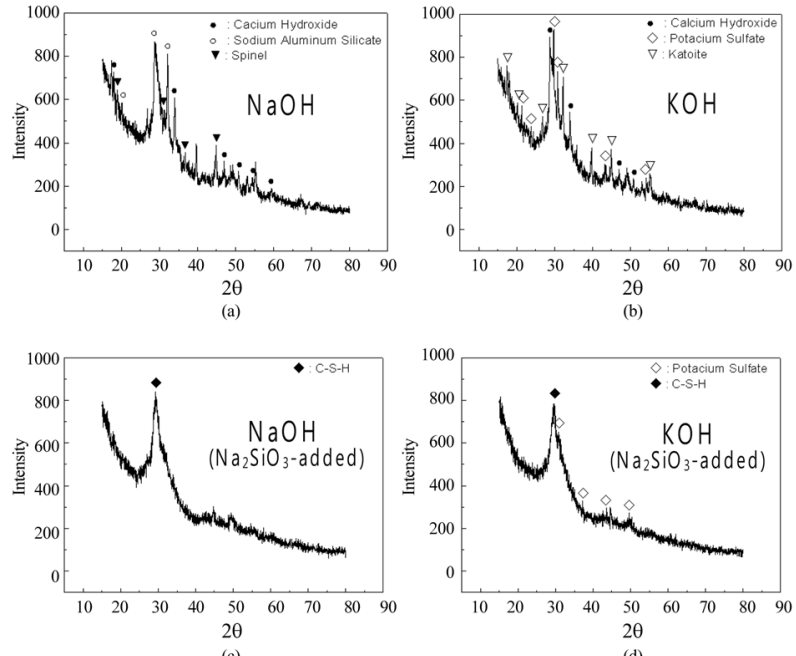

Fig. 9. XRD patterns of hardened slag geopolymer prepared with various alkaline solutions concentrated at $9 \mathrm{M}$ under the temperature of $60^{\circ} \mathrm{C}$ for $24 \mathrm{~h}$.

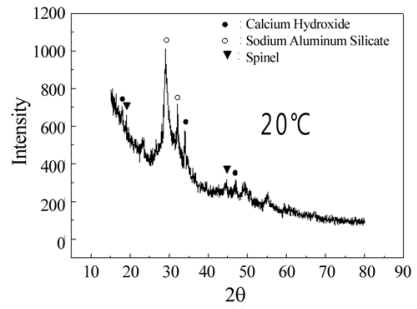

$2 \theta$
(a)

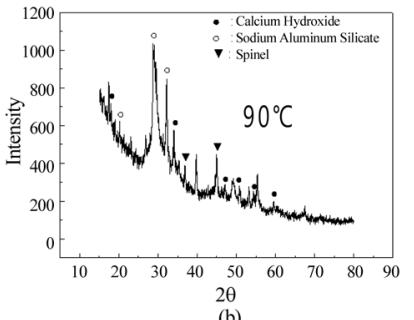

(b)
Fig. 10. XRD patterns of hardened slag geopolymer prepared with $9 \mathrm{M}-\mathrm{NaOH}$ at different temperature for $24 \mathrm{~h}$.

폴리머 반응과는 별도로 생성되어 잔존하는 것으로 보이는 $\mathrm{Ca}(\mathrm{OH})_{2}$ 피크가 확인되는데 이는 슬래그의 $\mathrm{Si}$ 와 $\mathrm{Al}$ 성분이 축중합 반응으로 소모됨으로서 가장 함량이 많던 $\mathrm{Ca}$ 성분 이 $\mathrm{CSH}$ 나 calcium aluminate hydrate $\left(\mathrm{C}_{3} \mathrm{AH}_{6}\right.$ 등) 상으로 생성 되지 못하고 독자적으로 수화하였기 때문일 것으로 생각 된다. 이러한 고찰은 $\mathrm{NaOH}$ 시료(그림 a)에서의 sodium aluminum silicate $\left(\mathrm{Na}_{2} \mathrm{AlSi}_{2} \mathrm{O}_{8}\right)$ 나 spinel $\left(\mathrm{MgAl}_{2} \mathrm{O}_{4}\right)$ 의 생성과 $\mathrm{KOH}$ 시료(그림 b)에서의 Katoite $\left[\mathrm{Ca}_{3} \mathrm{Al}_{2}\left(\mathrm{SiO}_{4}\right)_{1.5}(\mathrm{OH})_{6}\right]^{14)}$ 
의 생성이 뒷받침을 하고 있다. 이들 결정질 광물들은 출발 원료로 사용한 슬래그의 $\mathrm{X}$ 선 회절분석 결과(Fig. 1)에서는 전혀 나타나지 않은 것들이므로 고농도 알칼리용액에서 일 어난 축중합 반응 산물의 결정성이 발달하여 부분적으로 생성된 것으로 보이며 이는 슬래그의 지오폴리머 생성반응 이 제대로 진행되었음을 보여주는 결과라고 사료된다. 회절 pattern의 전체적인 형태로 보아 경화체는 이러한 소량의 결 정성 광물들이 비정질 상인 지오폴리머 및 저 결정성 $\mathrm{CSH}$ 상과 혼합된 상태일 것으로 짐작된다. 그러나 규산소다를 혼합한 용액으로 제조된 경화체(그림의 (c)와 (d))에서는 이들 결정성 광물의 피크가 없거나 현저히 감소(또는 은 폐 $)^{14,15)}$ 되고 $30^{\circ}$ 부근을 정점으로 halo 피크를 보이는 저 결정성 $\mathrm{CSH}$ 와 비정질 상이 대부분임을 알 수 있다. 규산소 다의 혼합만으로 이렇게 다른 결과를 나타내는 이유에 대 해서는 구체적인 구명이 계속되어야 하겠지만 우선은 규산 소다의 첨가로 용액 중의 $\mathrm{Si}$ 이온의 농도가 상승하여 $\mathrm{CSH}^{16)}$ 와 비정질 지오폴리머의 생성이 모두 다 촉진되었기 때문이 라는 점을 중요시해야할 것으로 보인다. 한편 $\mathrm{KOH}$ 를 사용 한 시료(그림의 (b))에서 나타나는 potassium sulfate는 슬 래그 중에 함유된 석고로부터 기인한 것이며 $\mathrm{NaOH}$ 를 사 용한 시료에서는 황화물은 확인되지 않았다. 또한 hydrotalcite $\left(\mathrm{Mg}_{6} \mathrm{Al}_{2} \mathrm{CO}_{3}(\mathrm{OH})_{16} \cdot 4 \mathrm{H}_{2} \mathrm{O}\right)$ 가 생성된 보고 ${ }^{17}$ 도 있 으나 본 연구에서는 슬래그 중의 $\mathrm{MgO}$ 함량이 적어 이러한 광물의 생성은 확인되지 않았다.

마지막으로 Fig. 9에는 $\mathrm{NaOH}$ 만을 사용하고 양생온도를 상온 $\left(20^{\circ} \mathrm{C}\right)$ 및 $90^{\circ} \mathrm{C}$ 로 변화하여 만든 경화체의 $\mathrm{X}$ 선 회절분 석 결과를 나타내었다. 이 결과와 $60^{\circ} \mathrm{C}$ 에서의 $\mathrm{NaOH}$ 시료의 결과(Fig. 9(a))를 종합해보면 결정성 광물의 종류는 온도 의 영향을 받지 않는다는 것과 양생온도를 $60^{\circ} \mathrm{C}$ 이상으로 높여주면 상온에서보다 결정성 광물의 피크의 강도가 다소 높아지는 것을 알 수 있다. 이 또한 앞에서 고찰한 바와 같 이 슬래그의 지오폴리머 생성반응이 약간 상승된 양생온도 에 의해 촉진되었음을 보여주는 것이다.

\section{3. 결 론}

시멘트 혼합용으로 만들어진 고로슬래그 분말에 몇 가지 의 고농도 알칼리 용액을 혼합하여 지오폴리머를 합성하였 으며 그 과정에서 양생온도의 변화가 슬래그의 반응성과 경화거동에 중요한 영향을 미치는 것을 알았다.

물의 비점 이하에서의 슬래그 분말의 지오폴리머 생성반 응은 알칼리 활성화제의 종류나 농도 여하에 상관없이 온도 에 비례하여 촉진되며, 9몰 이하에서의 알칼리 용액 농도의 증가 또는 규산이온의 첨가는 양생온도의 고저에 상관없이 반응을 촉진시킨다. 따라서 이들 변수는 슬래그 페이스트의 응결시간과 반응열 및 경화체의 치밀도 제어 수단으로 활 용될 수 있을 것이다.
슬래그 지오폴리머 경화체의 광물상과 그 구성비는 양생 온도보다는 알칼리 용액의 화학종이나 규산이온의 존재 여 부에 크게 영향을 받으나 반응 산물의 생성량에 의존하는 경 화조직의 치밀도는 양생온도와 양생기간에 비례하여 향상된다.

따라서 양생온도는 독립적 또는 복합적 조절 변수로서 물성이 다른 다양한 슬래그 지오폴리머 제조에 유용하게 활용될 수 있을 것으로 보인다.

\section{Acknowledgment}

본 연구는 2010학년도 2학기 경남대학교 교내 학술진 흥연구비의 지원에 의해 이루어졌으므로 이에 감사드립니다.

\section{REFERENCES}

1. J. Davidovits, "Geopolymers and Geopolymeric New Materials," J. Therm. Anal., 35 [2] 429-41 (1989).

2. J. Davidovits, "Geopolymer Cement to Minimize Carbondioxide Greenhouse- warming," Ceram. Trans., 37 165-82 (1993).

3. J. S. J. van Deventer, J. L. Provis, P. Duxson, and G. C. Lukey, "Reaction Mechanisms in the Geopolymeric Conversion of Inorganic Waste to Useful Products," J. Hazard Mater, A139 506-13 (2007).

4. K. Komnitsas and D. Zaharaki, "Geopolymerisation: A Review and Prospects for the Minerals Industry," Miner. Eng., 20 1261-77 (2007).

5. P. Duxson and J. L. Provis, "Designing Precursors for Geopolymer Cements," J. Am. Ceram. Soc., 91 [12] 3864-69 (2008).

6. J. Davidovits, "Inorganic Polymeric New Materials," $J$. Therm. Anal., 37 1633-56 (1991).

7. A. Roy, P. J. Schilling, H. C. Eaton, P. G. Malone, W. Newell Brabston, and L. D. Wakeley, "Activation of Ground Blast-Furnace Slag by Alkali-Metal and Alkaline-Earth Hydroxides," $J$. Am. Ceram. Soc., 75 [12] 3233-40 (1992).

8. J. Bijin and H. Waltie, "Alkali Activated Slag-Fly Ash Cements," Am. Concr. Inst., 114 1565-78 (1989).

9. B. Talling, "Effect of Curing Conditions on Alkali-Activated Slag," Intl. Concr. Res. \& Info. Portal, 114 1485-500 (1989).

10. T. W. Cheng and J. P. Chiu, "Fire-resistant Geopolymer Produced by Granulated Blast Furnace Slag," Min. Eng., 16 [3] 205-10 (2003).

11. J. Davidovits, "Global Warming Impacts on the Cement and Aggregate Industries," World Resource Review, 6263 (1994).

12. C. S. Jeon and T. W. Song, "Properties of Self-hardened Inorganic Coating in the System Alumina-Silica-Calcium Oxide by the Reaction with Alkalies(in Korean)," J. Kor. Ceram. Soc., 47 [5] 381-86 (2010).

13. D. Krizan and B. Zivanovic, "Effects of Dosage and Modulus of Water Glass on Early Hydration of Alkali-slag Cements," Cement Concr. Res., 32 [8] 1181-88 (2002).

14. F. Puertas, S. Martnez-Ramrez, S. Alonso, and T. Vzquez, "Alkali-activated Fly Ash/Slag Cement Strength Behaviour and Hydration Products," Cement Concr. Res., 30 [10] 1625-32 (2000). 
15. D. M. Roy and G. M. Idorn, "Development of Structure and Properties of Blast Furnace Slag Cement," J. Am. Concr. Inst., 97 444-57 (1982).

16. J. W. Ahn, J. S. Cho, H. S. Kim, G. C. Han, and H. Kim, "Activation Property of Blast Furnace Slag by Alkaline Activator(in Korean)," J. Kor. Ceram. Soc., 40 [10] 1005-14 (2003).
17. J. E. Oh, Paulo J. M. Monteiro, S. S. Jun, Sejin Choi, and Simon M. Clark, "The Evolution of Strength and Crystalline Phases for Alkali-activated Ground Blast Furnace Slag and Fly Ash-based Geopolymers," Cement Concr. Res., 40 [2] 18996 (2010). 